\title{
EFFECT OF BIOLOGICAL CHEMICAL AND BIOCHEMICAL TREATMENTS ON CHEMICAL COMPOSITION OF SUGAR CAN BAGASSE IN THE DEVELOPED BIOREACTOR
}

\author{
M. M. M. N. Khalil ${ }^{1 *}$ and H. M. El-Kony ${ }^{2}$
}

${ }^{1}$ Ag. Eng. Res. Inst., Ag. Res. Centre, Dokki, Giza, Egypt.

${ }^{2}$ Soil water and Environ. Res. Inst., Ag. Res. Centre, Dokki, Giza, Egypt.

*mn26253@gmail.com

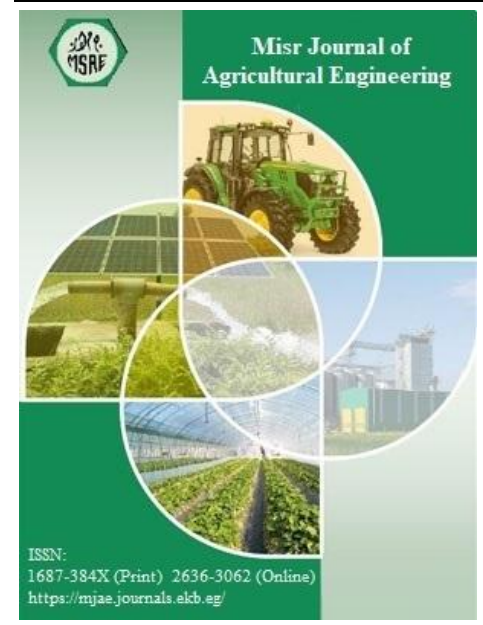

C Misr J. Ag. Eng. (MJAE)

Keywords:

Developed bioreactor, sugar can bagasse, biological treatment, chemical treatment, biochemical treatment

\section{ABSTRACT}

This experimental work was conducted during December 2017 at Tractors and Farm machinery Testing \& Research Station at Sabahia, Alexandria Governorate, Egypt. The present work is aimed to study the effect of treating of sugarcane bagasse biologically in a developed reactor, chemically and biochemically, as feeds for ruminants. Treatments were chemical (4\% urea), biological "Trichoderma harzinaum F-418 fungi", and biochemical treatment (combined biological + urea). The effect of different treatments on chemical composition of sugarcane bagasse were studied. Chemical composition, in terms of crude protein content "CP" (\%), crude fiber content "CF" (\%), Ether extract content "EE" (\%), ASH content "Ash" (\%) and Nitrogen free extract content "NFE" (\%) to maximize its nutritional values in order to use such improved materials as animal feeds. The results showed that different treatments increased CP, and ash, while decreased CF, EE and NFE. The increments in CP content were 415.56, 248.89 and 169.44\% due to biochemical, chemical and biological treatments, respectively. While the decrement in CF content were 28.99, 24.75 and $7.54 \%$ due to biochemical, chemical and biological treatments, respectively.

\section{INTRODUCTION}

$\mathrm{H}$ amdia et al., (2011), mentioned that in Egypt, a feed is an important one of production inputs; its value is represented about $58.3 \%$ of the total value of agricultural production inputs in 2008. There are about 12 million animal units, the needs of those animal units of green feed were estimated about 39.8 million tons, about 9.6 million tons of straw, and about 15.9 million tons of concentrated feed. These needs were estimated at about 18.4 million tons of starch equivalent, and about 2.1 million tons of protein digested. The available quantity for consumption of feed was estimated about 64.8 million tons of green feed, about 9.2 million tons of straw, and about 5.1 million tons of concentrated feed. The available quantity for consumption were estimated at about 11.6 million tons of starch equivalent, and about 1.8 million tons of protein digested during the average period (2003-2008). By 
Estimating the feed balance in Egypt during the average period (2003-2008), showing a surplus in the green feed is estimated at about 24.9 million tons, also showing a deficit in the straw and the concentrated feed about $0.4,10.9$ million tons respectively. This noted a deficit estimated at about 6.8 million tons of starch equivalent and about 225.2 thousand tons of digested protein. Abd El-Azim et al., (2011), showed that in Egypt about 21.542 million tons of plant by-products produced annually. Two thirds of the crop residues are burned or wasted, and lead to environmental pollution and consequently health hazards. Barnes, (1980) showed that Sugar cane bagasse (SCB) is a secondary by-product of sugar cane extraction factories. It is used in the manufacture of pressed fibrous woods, paper pulp and as fuel. Bagasse represents 30-32\% of the sugar cane plant. EL-Shinnawy, (1990) mentioned that the annual production of SCB in Egypt is in the order of one million metric tons / year. Also Hamdia et al., (2011), showed that Sugar cane bagasse (SCB) is not being used at present, and generally is burned. The high lignin content is a challenge, and the development of a method to upgrade bagasse as a digestible fiber source or as a substrate for single-cell protein production would be useful. There is a possibility of using bagasse in livestock feeding, while the use of by-products in animal nutrition is a necessity, since it may increase the availability of food for mankind as well as avoid accumulation that contributes to environmental problems. Sugar cane bagasse is the most abundant by-product in Egypt. Poor intake, due to low digestibility and low energetic density, are considered the main reasons for unsatisfactory performance of animals fed such roughage. Fouda (2008) mentioned that there is a wide gap between the available feedstuffs and farm animal's requirements. The available local feedstuffs are not sufficient completely to cover the nutritional requirements of the Egyptian live stocks. Due to the annually increased prices of the available feed resources; nutritionists do their efforts to improve the nutritional values of such resources. In addition, they are looking for contribution to the available negligible agricultural by-products to provide additional marginal resources. Different treatment techniques and methods are being applied to improve the nutritional values of the additional roughage resources. El-Shinnawy and Shoukry, (2002) estimated that the amount of poor quality roughages in Egypt includes rice straw, wheat straw, bean straw, corn stalks, corn cobs, rice hulls and sugarcane bagasse is about 19 million tons/ year. While (Conrad et al., 1990) \& Molina, 1990) mentioned that Among these roughages, sugarcane bagasse represents about 4.13 million tons/ year according to Agriculture Economic and Statistics Institute (1995). Under this circumstance, sugar cane becomes important as a potential feed resource given its high biomass yield and adaptation to the environment. (Shoukry et al., 1992 \& Fouad et al., 1998) showed that Sugarcane bagasse, filter cake and pith are secondary by-products in the process of sugar production. The main components of them are cellulose, hemicellulose and lignin. As a result of its high content of lignin, ruminal digestion is inhibited and thus, the nutritive value of bagasse and pith is low for ruminants and to improve the nutritive value of these agriculture residues, it is important to breakdown the linkages among cellulose and lignin by mechanical, chemical or biological and combined biological plus chemical treatments. Many scientists suggested the use of ammonia and urea to increase the crude protein contents of the poor quality roughages. El-Ashry et al., (2002), mentioned that Physical and chemical pre-treatment such as ammonia explosion in combination with fungal may also upgrade the nutritional quality of marginal agricultural residues such as bagasse. Biological treatment is an alternative method 
to modify the fibrous materials by ruminants. The mode of fungal decay on roughages using the white rot fungi was shown to improve in vitro dry matter digestibility of the decayed substrate (Dawson et al.,1990). Recently the production of microbial protein from agricultural crop residues received that attention of several workers. Khairy (2015), developed a simple bioreactor to enrich the protein of rice straw using solid-state fermentation, he studied two operational parameters, three levels of substrate temperatures $\left(25,35\right.$ and $\left.45^{\circ} \mathrm{c}\right)$ and three levels of substrate moisture content $(25,50$ and $65 \%)$. The fermentation time was 5 days and parameters related to microbial growth crude protein content $\%(\mathrm{CP} \%)$, and crude fiber content $\%(\mathrm{CF} \%)$ were measured every $24 \mathrm{hr}$. The highest crude protein and the lowest crude fiber values were obtained at the temperature $30-35^{\circ} \mathrm{c}$ and the moisture content $65 \%$ after 4 and 5 days. The best value of crude protein was $5.88 \%$ which increased $103 \%$ of the control treatment and the best value of crude fiber content was $28.35 \%$ by decreasing (30\%) of control treatment. It is evident that these values demonstrated good operation of fermentation in bioreactor. Nabih (2015) studied Six operational parameters with three replicates were applied in in the bioreactor of $100 \mathrm{~L}$ capacity. Three levels of substrate loading of 1, 2 and $3 \mathrm{~kg}$ of treated rice straw, two condition of flowing ambient and moist air flow, fermentation time 5 days which leads to 18 experiments to determined the optimum conditions of fungal treatment in terms of load and condition of aeration under solid state fermentation by Trichoderma harzinaum F-418 fungi, molasses and valvic solution additive, temperature "T" $\left(35^{\circ} \mathrm{c}\right)$, moisture content "M" $(65 \%)$, the ambient air and moist air was fed at constant flow rate of $0.15 \mathrm{~L} \mathrm{~h}^{-1} \mathrm{~g}$-dry-substrate ${ }^{-1}$ into the bioreactor, rotating of paddle mixer at $50 \mathrm{rpm}$ once every $24 \mathrm{~h}(15 \mathrm{~min})$ before taking samples. The maximum value of crude protein content "CP" (\%) was $7.95 \%$ at substrate loading $2 \mathrm{~kg}$ at moist air flow after 3 days but the opposite results were found for the loading of $3 \mathrm{~kg}$.

\section{MATERIALS AND METHODS}

This study was carried out at Tractors and Farm machinery Testing \& Research Station at Sabahia, Alexandria Governorate, Egypt.

\subsection{Chemical composition of sugar cane bagasse.}

Chemical composition of sugarcane bagasse $\%$ as reported by some authors is shown in Table (1). Their findings showed that sugar cane bagasse contains in percentages, DM ( 88.63-94.57) with an average of 90.48 ; CP (1.0-3.95) with an average of 2.47; EE ( 0.7-4.05) with an average of 2.61 ; CF ( 27.85-51.78) with an average of 41.35 ; N-free extract ( 36.82-56.40) with an average of 47.32; OM , (90.05-94.69) with an average of 92.39; Ash (3.00-9.95) with an average of 6.46; ADF, (59.0-65.77) with an average of 62.38 and NDF, (80.95-86.0) with an average of 83.47 .

Table (1) Chemical composition of sugar cane bagasse \% by some authors (2003):

\begin{tabular}{|c|c|c|c|c|c|c|c|c|c|}
\hline Authors & DM & OM & CP & CF & EE & NFE & ASH & ADF & NDF \\
\hline Shakweer & 94.57 & 92.44 & 2.66 & 36.78 & 4.05 & 48.75 & 7.56 & 65.77 & 80.95 \\
\hline Bassuny & 88.63 & 94.69 & 2.26 & 51.78 & 3.83 & 36.82 & 5.31 & - & - \\
\hline Preston & 91.00 & - & 1.00 & 49.00 & 0.7 & - & 3.00 & 59.00 & 86.00 \\
\hline Boraei & 89.14 & 90.05 & 3.95 & 27.85 & 1.85 & 56.40 & 9.95 & - & - \\
\hline Average & 90.48 & 92.39 & 2.47 & 41.35 & 2.61 & 47.32 & 6.46 & 62.38 & 83.47 \\
\hline
\end{tabular}

Where:

DM: dry matter, OM: organic matter, CP: crude protein, CF: crude fiber, EE: ether extract, NFE: nitrogen free extract, ADF: neutral detergent fiber and ADF: acid detergent fiber 


\subsection{Sugarcane by-product preparation:}

Bagasse type of low quality roughages was obtained from one of the contemporary reeds kafer El-dawar El-Beheira Government, was sun dried to 90\% DM and was chopped handly by a small cutter to $1-3 \mathrm{~cm}$ of length according to Smail et al., (1995).

\subsection{Biological treatment:}

The tested type of fungal strain "Trichoderma harzinaum F-418 fungi" was obtained from the Microbial Chemistry Laboratory, National Research Center, Dokki, Giza, Egypt. The fungal strain was cultured in a media contained the following substances per one liter: $1.0 \mathrm{~g}$ urea /1 (1\% molasses solution ), $1.0 \mathrm{~g}$ ammonium sulphate, $1.0 \mathrm{~g}$ potassium dihydrogen phosphate and $0.25 \mathrm{~g}$ solid magnesium sulphate: liquid ratio 1:2. Fifty $\mathrm{ml}$ of the previous media was incubated in $250 \mathrm{ml}$ conical flask. The flasks were sterilized by autoclave at $121 \mathrm{oC}$ for 20 minutes. The cooled sterilized flasks were inoculated with above prepared inoculum, then incubated at room temperature under static condition for three days. The growing fungal mycelium was employed by $5 \%$ to inoculate the experimental flasks. Samples of sugar cane bagasse.

Stirred-drum of bioreactor was developed to allow adequate mixing of the sugar can bagass and aeration. Mixing and aeration of the medium has been done by some devices such as paddles, and two inlet vertical pipes with whose diameter of $1.27 \mathrm{~cm}$ and excess gas escaping through an outlet valve. Three temperature probes were installed through the bioreactor bed and arranged radially with equal distances to indicate the bed temperature. Mechanical thermostat composed of heater, control lever and probe was used to adapt the bed temperature to the optimum temperature $\left(35^{\circ} \mathrm{c}\right)$. laboratory experiments were done in the bioreactor of $100 \mathrm{~L}$ capacity to study the effect of substrate loading of $2 \mathrm{~kg}$, aeration characteristics (ambient air) and biological treatment (20\% Trichoderma harzinaum F-418 fungi, 2\% molasses and 4\% valvic solution respectively by weight) on chemical composition of the treated sugar cane bagasse during 5 days fermentation time.

\subsection{Chemical treatment:}

The required amount of urea $(40 \mathrm{~g})$ was dissolved in $500 \mathrm{ml}$ water and sprayed on $1 \mathrm{~kg}$ of chopped sugarcane bagasse. The treated bagasse was thoroughly to be homogenous then ensiled up to 3 weeks. One chemical substances was being also tested in this study: urea treatment (4\%) and at different incubation periods (7, 14, 21 and 28 days). Samples of sugar cane bagasse (each of $200 \mathrm{~g}$ ), was treated with either urea solution, (v/w) at the previous concentrations and incubation periods. The treated material (sugar cane bagasse) with a moisture content adjusted to approximately $65 \%$ were bagged in air tight polyethylene sheets. After different incubation period, the chemical treated bagasse samples were taken out to be aerated for 2 days to get rid of the free ammonia and smell. Then sugar cane bagasse samples were ground and stored in a glass bottle for later chemical analysis.

\subsection{Biochemical treatment:}

At the end of fermented period of biological sugarcane bagasse, it aerate overnight then mixed well with urea then bagged and stored up to 28 days.

\subsection{Statistical analysis:}

Randomized Complete Block (RCP) in three replications was used in this study. Least Significant Differences at 0.05 probability level (LSD 0.05) was calculated to compare the differences between treatment means according to Snedecor and Cochran (1971). 


\section{RESULTS AND DISCUSSION}

The present study was conducted to clarify the effects of biological treatments with Trichoderma harzianum fungi $20 \%$ by weight, chemical treatment by urea $4 \%$ and biochemical treatment by fungi plus urea $4 \%$ on chemical composition of treated sugar cane bagasse.

\subsection{Effect of biological treatments on the chemical composition of treated sugar cane bagasse. (SCB ):}

1- crude protein content "CP" (\%)

The effect of biological treatment on crude protein content "CP" (\%) in bioreactor at different rotation rate of the agitator "S" (15, 30 and $45 \mathrm{rpm})$ and three flow rate of inlet air $(0.10,0.15$ and $0.20 \mathrm{Lh}^{-1} \mathrm{~g}$-dry-substrate) with Trichoderma harzinaum F-418 (TH) is shown in Table (4.1) and Fig. (4.1). Crude protein content $\mathrm{CP} \%$ increased with fermentation time until 5 days for all rotation rate of the agitator "S" $(15,30$ and $45 \mathrm{rpm})$ and flow rate of inlet air $(0.10,0.15$ and $0.20 \mathrm{Lh}^{-1} \mathrm{~g}$-dry-substrate) under study, the maximum values of crude protein content "CP" (\%) was $4.85 \%$ for rotation rate of the agitator "S" of $45 \mathrm{rpm}$ and flow rate of inlet air of $0.15 \mathrm{Lh}^{-}$ ${ }^{1} \mathrm{~g}$-dry-substrate) after fermentation time of 4 days. The higher crude protein content "CP" (\%) may be due to the capture of excess nitrogen by aerobic microbes and conversion of the same into microbial protein during solid-state fermentation. Similar results were reported by Langar et al. (1980); or may be referred to the available fermentable sugars released as a result to the hydrolyzing enzymes of the fungus on the substrate which led to stimulate the fungus to produce high levels of activated enzymes. These results agreed well with those found by Shoukry et al., (1985) and Ahuja et al., (1986).

\section{2- Crude Fiber "CF" (\%)}

The effect of biological treatment on crude fiber content "CF" (\%) in bioreactor at different rotation rate of the agitator "S" (15, 30 and $45 \mathrm{rpm})$ and three flow rate of inlet air $(0.10,0.15$ and $0.20 \mathrm{Lh}^{-1} \mathrm{~g}$-dry-substrate) in Bioreactor with Trichoderma harzinaum F-418 (TH) is shown in Table (4.1) and Fig. (4.1). Crude fiber content CP\% decreased with fermentation time until 5 days for all rotation rate of the agitator "S" (15, 30 and $45 \mathrm{rpm})$ and flow rate of inlet air $(0.10$, 0.15 and $0.20 \mathrm{Lh}^{-1} \mathrm{~g}$-dry-substrate) under study, the minimum value of crude fiber content "CF" (\%) was $45.77 \%$ for rotation rate of the agitator "S" of $45 \mathrm{rpm}$ and flow rate of inlet air of 0.15 $\mathrm{Lh}^{-1} \mathrm{~g}$-dry-substrate) after fermentation time of 4 days. Reduction of crude fiber content "CF" (\%) may be due to utilization of crude fiber content "CF" (\%) by microorganism for its growth, and these findings confirm those obtained by Shahjahan et al., (1986) and Bakchevanska (1988). Or may be referred to the available fermentable sugars released as a result to the hydrolyzing enzymes of the fungus on the substrate which led to stimulate the fungus to produce high levels of activated enzymes. Moreover, fungus treatments were more effective in degrading the crude fiber content "CF" (\%) may be to that the hyphae of the fungus is capable to deeply penetrate into the residue as well as into intracellular spaces of the residue; meanwhile the fungus not only grew at the surface of the substrate but actually deeply penetrates into the intracellular spaces of the residue. These results agreed well with those found by Shoukry et al., (1985) and Ahuja et al., (1986) who reported that, CF content decreased in rice straw when treated with fungi.

\section{3- Ether Extract "EE" (\%)}

Data presented in Table (4.1) and Fig. (4.1) showed the effect of biological treatment on Ether extract content "EE" (\%) in bioreactor at different rotation rate of the agitator "S" (15, 30 and 
$45 \mathrm{rpm})$ and three flow rate of inlet air $\left(0.10,0.15\right.$ and $0.20 \mathrm{Lh}^{-1} \mathrm{~g}$-dry-substrate) in Bioreactor with Trichoderma harzinaum F-418 (TH). Ether extract content "EE" (\%) decreased with fermentation time until 5 days for the rotation rate of the agitator "S" (15, 30 and $45 \mathrm{rpm}$ ) and three flow rate of inlet air $\left(0.10,0.15\right.$ and $0.20 \mathrm{Lh}^{-1} \mathrm{~g}$-dry-substrate). The minimum value of Ether extract content "EE" (\%) was $1.13 \%$ for rotation rate of the agitator "S" of $45 \mathrm{rpm}$ and flow rate of inlet air of $0.15 \mathrm{Lh}^{-1} \mathrm{~g}$-dry-substrate) after fermentation time of 4 days. The decrease in Ether extract content "EE" (\%) is may be due to consuming of some fatty acids by fungi as a suitable energy source for growth These findings confirm those obtained by (Kholif, 2001).

\section{4- Nitrogen Free Extract "NFE" (\%),}

Data presented in Table (4.1) and Fig. (4.1) showed the effect of biological treatment on Nitrogen Free Extract "NFE" (\%) in bioreactor at different rotation rate of the agitator "S" (15, 30 and $45 \mathrm{rpm})$ and three flow rate of inlet air $\left(0.10,0.15\right.$ and $0.20 \mathrm{Lh}^{-1} \mathrm{~g}$-dry-substrate) in Bioreactor with Trichoderma harzinaum F-418 (TH). Nitrogen Free Extract "NFE" (\%) decreased with fermentation time until 5 days for the rotation rate of the agitator "S" $(15,30$ and $45 \mathrm{rpm})$ and three flow rate of inlet air $\left(0.10,0.15\right.$ and $0.20 \mathrm{Lh}^{-1} \mathrm{~g}$-dry-substrate). The minimum value of Nitrogen Free Extract "NFE" (\%) was $38.02 \%$ for rotation rate of the agitator "S" of $45 \mathrm{rpm}$ and flow rate of inlet air of $0.15 \mathrm{Lh}^{-1} \mathrm{~g}$-dry-substrate) after fermentation time of 4 days. The decrease in Nitrogen Free Extract "NFE" (\%) is may be be due to the increase in ash content and the decrease in "EE" at the same time.

\section{5 - ASH "ash" (\%)}

Data presented in Table (4.1) and Fig. (4.1) showed the effect of biological treatment on ASH "ash" (\%) in bioreactor at different rotation rate of the agitator "S" (15, 30 and $45 \mathrm{rpm})$ and three flow rate of inlet air $\left(0.10,0.15\right.$ and $0.20 \mathrm{Lh}^{-1}$ g-dry-substrate) in Bioreactor with Trichoderma harzinaum F-418 (TH). ASH "ash" (\%) increased with fermentation time until 5 days for the rotation rate of the agitator "S" $(15,30$ and $45 \mathrm{rpm})$ and three flow rate of inlet air (0.10, 0.15 and $0.20 \mathrm{Lh}^{-1} \mathrm{~g}$-dry-substrate). The maximum value of ASH "ash" (\%)was $10.22 \%$ for rotation rate of the agitator "S" of $45 \mathrm{rpm}$ and flow rate of inlet air of $0.15 \mathrm{Lh}^{-1} \mathrm{~g}$-drysubstrate) after fermentation time of 4 days. The increase in ASH "ash" (\%) is may be may be a reflections of degrading the crude fiber of the tested roughage substance (Abd-Allah, 2007). The statistical analysis of crude protein content "CP" (\%), Crude Fiber "CF" (\%), Ether Extract "EE" (\%), Nitrogen Free Extract "NFE" (\%), ASH "ash" (\%) are tabulated in Table 3.1 showed that the means of crude protein content "CP" (\%), Crude Fiber "CF" (\%), Ether Extract "EE" (\%), Nitrogen Free Extract "NFE" (\%), ASH "ash" as affected by every factors under study to examine by LSD (Least Significant Difference) test if any significant difference at $5 \%$ level of probability from one to another and from the rest of the groups of rotation rate of the agitator "S" (15, 30 and $45 \mathrm{rpm})$, these differences were significantly among groups of flow rate of inlet air $\left(0.10,0.15\right.$ and $0.20 \mathrm{Lh}^{-1} \mathrm{~g}$-dry-substrate and these differences were significantly among of rotation rate of the agitator "S" (15, 30 and $45 \mathrm{rpm})$. Generally the Data of crude protein content "CP" (\%), Crude Fiber "CF" (\%), Ether Extract "EE" (\%), Nitrogen Free Extract "NFE" (\%), ASH "ash" (\%) are presented in (Table 3.1) and Fig. (3.1) showed that the results optimum of biological treatment were at rotation rate of the agitator "S" of $45 \mathrm{rpm}$ and flow rate of inlet air of $0.15 \mathrm{Lh}^{-1} \mathrm{~g}$-dry-substrate) after fermentation time of 4 days. 
Table (4.1), Crude protein "CP" (\%), Crude Fiber "CF" (\%), Ether Extract "EE" (\%), Nitrogen Free Extract "NFE" (\%), ASH "ash" (\%) at different fermentation time "FT" (days), three rotation rate of the agitator " $S$ " $(15,30$ and $45 \mathrm{rpm})$, and three flow rate of inlet air $(0.10,0.15$ and $0.20 \mathrm{Lh}^{-1}$ g-dry-substrate) in Bioreactor.

\begin{tabular}{|c|c|c|c|c|c|c|}
\hline \multirow[t]{2}{*}{ S (RPM) } & \multirow[t]{2}{*}{ Air rate $(\mathrm{L} / \mathrm{h})$} & \multicolumn{5}{|c|}{ FERMENTATION TIME (DAYS) } \\
\hline & & 1 & 2 & 3 & 4 & 5 \\
\hline \multirow{4}{*}{15} & \multicolumn{6}{|c|}{ Crude protein "CP" (\%) } \\
\hline & 0.10 & 2.22 & 3.29 & 3.85 & 4.40 & 4.36 \\
\hline & 0.15 & 2.25 & 3.32 & 3.38 & 4.43 & 4.39 \\
\hline & 0.20 & 2.24 & 3.31 & 3.37 & 4.42 & 4.38 \\
\hline \multirow{3}{*}{30} & 0.10 & 2.44 & 3.51 & 3.57 & 4.62 & 4.58 \\
\hline & 0.15 & 2.45 & 3.52 & 3.58 & 4.63 & 4.59 \\
\hline & 0.20 & 2.42 & 3.49 & 3.55 & 4.60 & 4.56 \\
\hline \multirow{3}{*}{45} & 0.10 & 2.46 & 3.53 & 3.59 & 4.64 & 4.60 \\
\hline & 0.15 & 2.67 & 3.25 & 3.95 & 4.85 & 4.81 \\
\hline & 0.20 & 2.50 & 3.57 & 3.63 & 4.68 & 4.75 \\
\hline \multirow{4}{*}{15} & \multicolumn{6}{|c|}{ Crude Fiber "CF" (\%), } \\
\hline & 0.10 & 48.65 & 47.96 & 46.95 & 46.25 & 46.35 \\
\hline & 0.15 & 48.55 & 47.83 & 46.89 & 46.15 & 46.50 \\
\hline & 0.20 & 48.50 & 47.45 & 46.85 & 45.98 & 46.00 \\
\hline \multirow{3}{*}{30} & 0.10 & 48.41 & 47.35 & 46.84 & 45.95 & 45.99 \\
\hline & 0.15 & 48.40 & 47.30 & 46.35 & 45.95 & 45.97 \\
\hline & 0.20 & 48.38 & 47.25 & 46.25 & 45.91 & 45.92 \\
\hline \multirow{3}{*}{45} & 0.10 & 48.35 & 46.95 & 46.00 & 45.86 & 45.88 \\
\hline & 0.15 & 48.30 & 46.94 & 45.97 & 45.77 & 45.89 \\
\hline & 0.20 & 48.35 & 46.92 & 44.78 & 45.83 & 45.79 \\
\hline \multirow{4}{*}{15} & \multicolumn{6}{|c|}{ Ether Extract "EE" (\%), } \\
\hline & 0.10 & 1.160 & 1.155 & 1.154 & 1.153 & 1.153 \\
\hline & 0.15 & 1.159 & 1.158 & 1.156 & 1.152 & 1.150 \\
\hline & 0.20 & 1.158 & 1.156 & 1.155 & 1.150 & 1.150 \\
\hline \multirow{3}{*}{30} & 0.10 & 1.157 & 1.155 & 1.150 & 1.148 & 1.150 \\
\hline & 0.15 & 1.156 & 1.155 & 1.150 & 1.147 & 1.150 \\
\hline & 0.20 & 1.155 & 1.153 & 1.150 & 1.140 & 1.150 \\
\hline \multirow{3}{*}{45} & 0.10 & 1.156 & 1.150 & 1.145 & 1.140 & 1.144 \\
\hline & 0.15 & 1.155 & 1.150 & 1.140 & 1.130 & 1.135 \\
\hline & 0.20 & 1.160 & 1.155 & 1.150 & 1.140 & 1.150 \\
\hline \multirow{4}{*}{15} & & itrogen & ee Extr & "NFE" & $\%)$ & \\
\hline & 0.10 & 42.24 & 40.79 & 40.24 & 38.74 & 39.24 \\
\hline & 0.15 & 42.24 & 40.75 & 40.14 & 38.54 & 39.04 \\
\hline & 0.20 & 42.24 & 40.35 & 40.00 & 38.44 & 38.94 \\
\hline \multirow{3}{*}{30} & 0.10 & 42.24 & 40.15 & 39.97 & 38.40 & 38.90 \\
\hline & 0.15 & 42.24 & 40.05 & 39.95 & 38.38 & 38.88 \\
\hline & 0.20 & 42.24 & 39.95 & 39.90 & 38.35 & 38.85 \\
\hline \multirow{3}{*}{45} & 0.10 & 42.24 & 39.92 & 39.85 & 38.25 & 38.75 \\
\hline & 0.15 & 42.24 & 39.90 & 39.80 & 38.02 & 38.52 \\
\hline & 0.20 & 42.24 & 39.95 & 40.24 & 38.74 & 39.24 \\
\hline
\end{tabular}




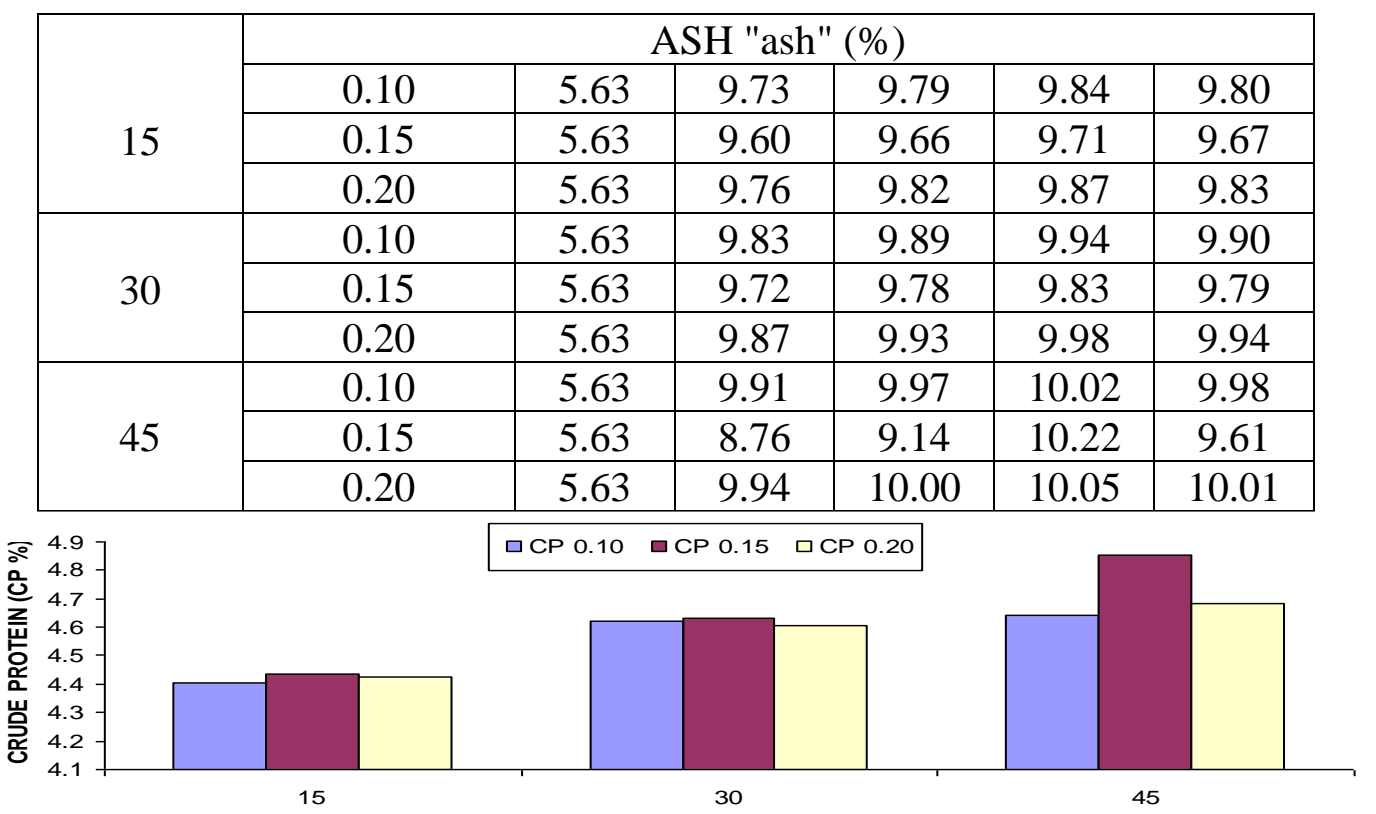

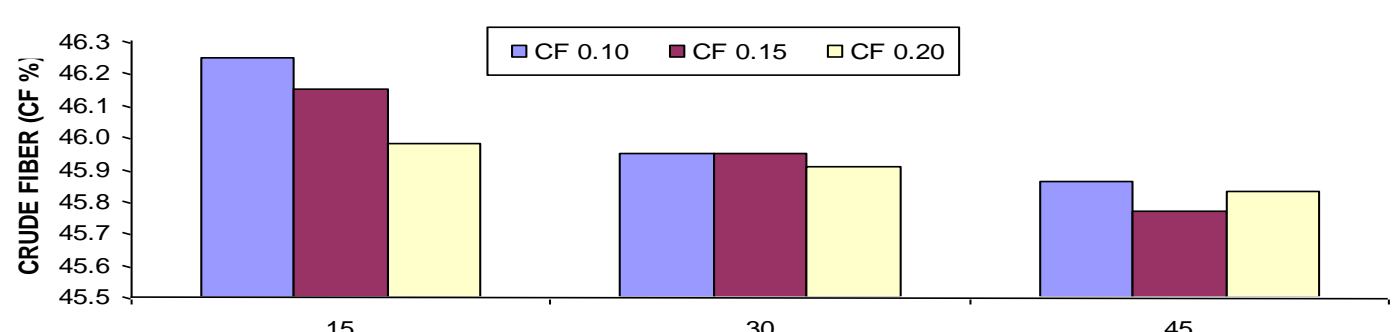

15

30

45
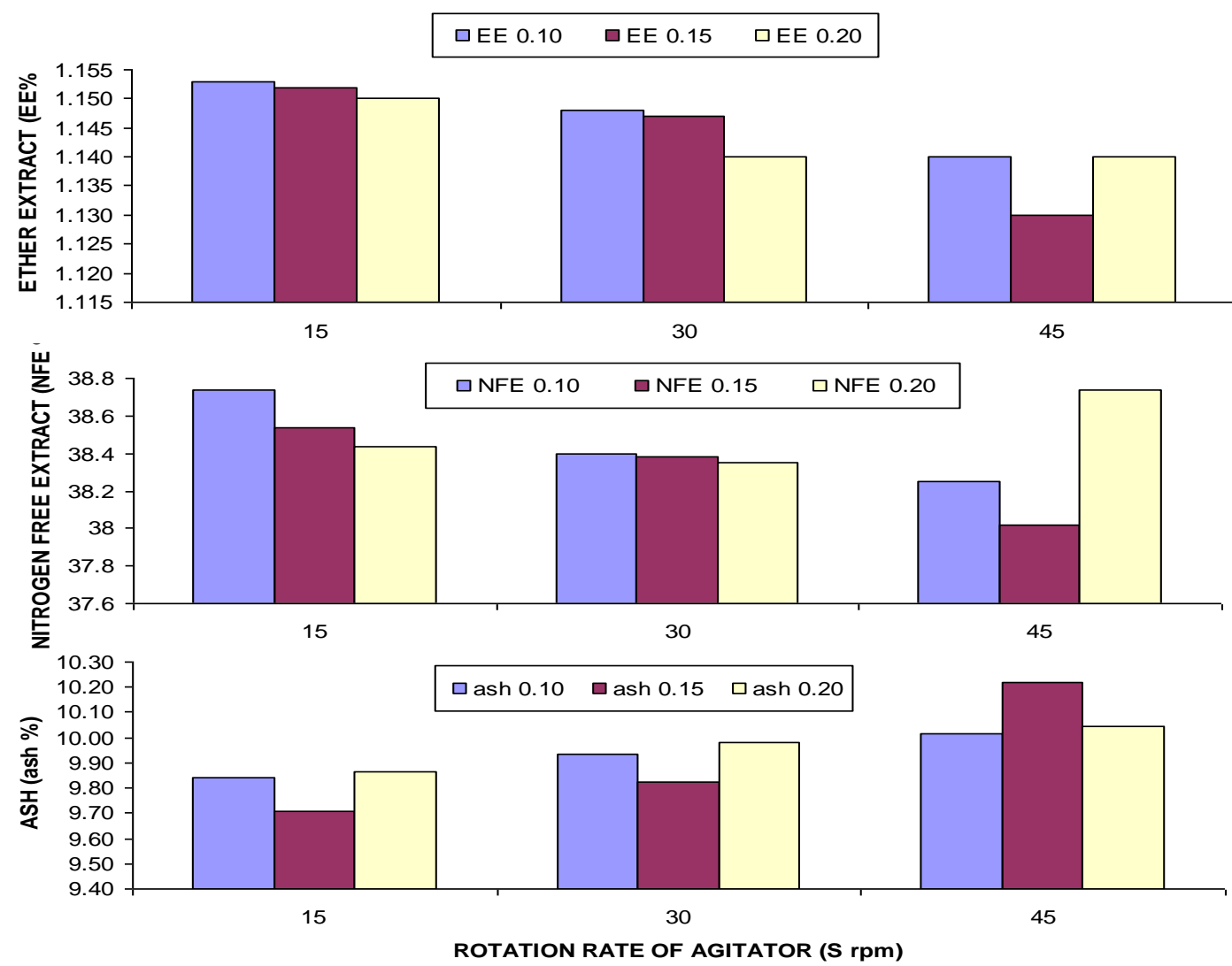

Fig (4.1), Crude protein "CP" (\%), Crude Fiber "CF" (\%), Ether Extract "EE" (\%), Nitrogen Free Extract "NFE" (\%), ASH "ash" (\%) at three rotation rate of the agitator "S" (15, 30 and $45 \mathrm{rpm})$, and three flow rate of inlet air $\left(0.10,0.15\right.$ and $0.20 \mathrm{Lh}^{-1} \mathrm{~g}$-dry-substrate) in Bioreactor. 
4.2 Effect of chemical treatment by urea $4 \%$ on the chemical composition of treated sugar cane bagasse. (SCB):

Data presented in (Table 4.2) and Fig. (4.2) showed the effect of treatment of sugar cane bagasse. (SCB) by urea as chemical treatment to determine the improvement of the chemical treatment on the Crude protein "CP" (\%), Crude Fiber "CF" (\%), Ether Extract "EE" (\%), Nitrogen Free Extract "NFE" (\%), ASH "ash" (\%)

Table (4.2): crude protein (CP\%), crude Fiber (CF\%), Ether Extract (EE\%), Ash (\%) and Nitrogen free extract (NFE\%) at different fermentation for chemical treatment (urea treatment).

\begin{tabular}{|c|c|c|c|c|c|}
\hline $\begin{array}{c}\text { FERMENTATION } \\
\text { TIME (DAYS) }\end{array}$ & CP (\%) & CF (\%) & EE (\%) & NFE (\%) & Ash (\%) \\
\hline UNTREATED & 1.80 & 49.50 & 1.16 & 42.24 & 5.30 \\
\hline 7 & 4.08 & 42.44 & 1.12 & 40.15 & 12.21 \\
\hline 14 & 5.10 & 40.85 & 1.06 & 39.25 & 13.74 \\
\hline 21 & 6.15 & 38.55 & 0.95 & 38.45 & 15.90 \\
\hline 28 & 6.28 & 37.25 & 0.90 & 37.55 & 18.02 \\
\hline
\end{tabular}

4.3 Effect of biochemical treatment (biological treatment followed by urea $4 \%$ ) on the chemical composition of treated sugar cane bagasse. (SCB ):

Data presented in (Table 4.3) and Fig. (4.3) showed the effect of treatment of the resulted optimum biological treatment followed by urea $4 \%$ ) as a biochemical treatments (biological and chemical treatments) to determine the improvement of the chemical.

Table (4.3): crude protein (CP\%), crude Fiber (CF\%), Ether Extract (EE\%), Ash (\%) and Nitrogen free extract (NFE\%) at different fermentation time (days) for biochemical treatment.

\begin{tabular}{|c|c|c|c|c|c|}
\hline $\begin{array}{c}\text { FERMENTATION } \\
\text { TIME (DAYS) }\end{array}$ & CP $(\%)$ & CF $(\%)$ & EE (\%) & NFE (\%) & Ash (\%) \\
\hline UNTREATED & 1.80 & 49.50 & 1.16 & 42.24 & 5.30 \\
\hline BIO TREATED & 4.85 & 45.77 & 1.13 & 38.02 & 10.22 \\
\hline 7 & 7.08 & 42.65 & 1.00 & 36.55 & 12.72 \\
\hline 14 & 8.10 & 39.30 & 0.94 & 34.95 & 16.71 \\
\hline 21 & 9.15 & 37.55 & 0.85 & 34.00 & 18.45 \\
\hline 28 & 9.28 & 35.15 & 0.75 & 34.25 & 20.57 \\
\hline
\end{tabular}

\section{Dray matter (DM):}

Results of chemical composition of untreated and treated bagasse with different treatments are presented in Table (4). The data obtained showed that DM content was increased after treatment in different cases, the highest DM content was observed in bagasse treated with $4 \%$ urea (96.2\%). On the contrary, the lowest value was recorded in untreated bagasse (91.9\%). On the other hand, biochemical treatment showed higher value (95.31) in comparison with the biological treatment (94.15).

\section{Organic matter (OM):}

Higher OM value was recorder with untreated $(94.70 \%)$. On the contrast the lowest value $(88.52 \%)$ was recorded in biochemical treatment, while untreated and treated bagasse with urea indicated intermediate values (94.7 and 92.3\%). These results agree with those obtained by Chandra et al. (1991) who found that the decreased OM was a reflection to decrease in CF which was utilized by fungi, while the increase in total ash was inversely related to the OM content of treated sugar can bagass. 

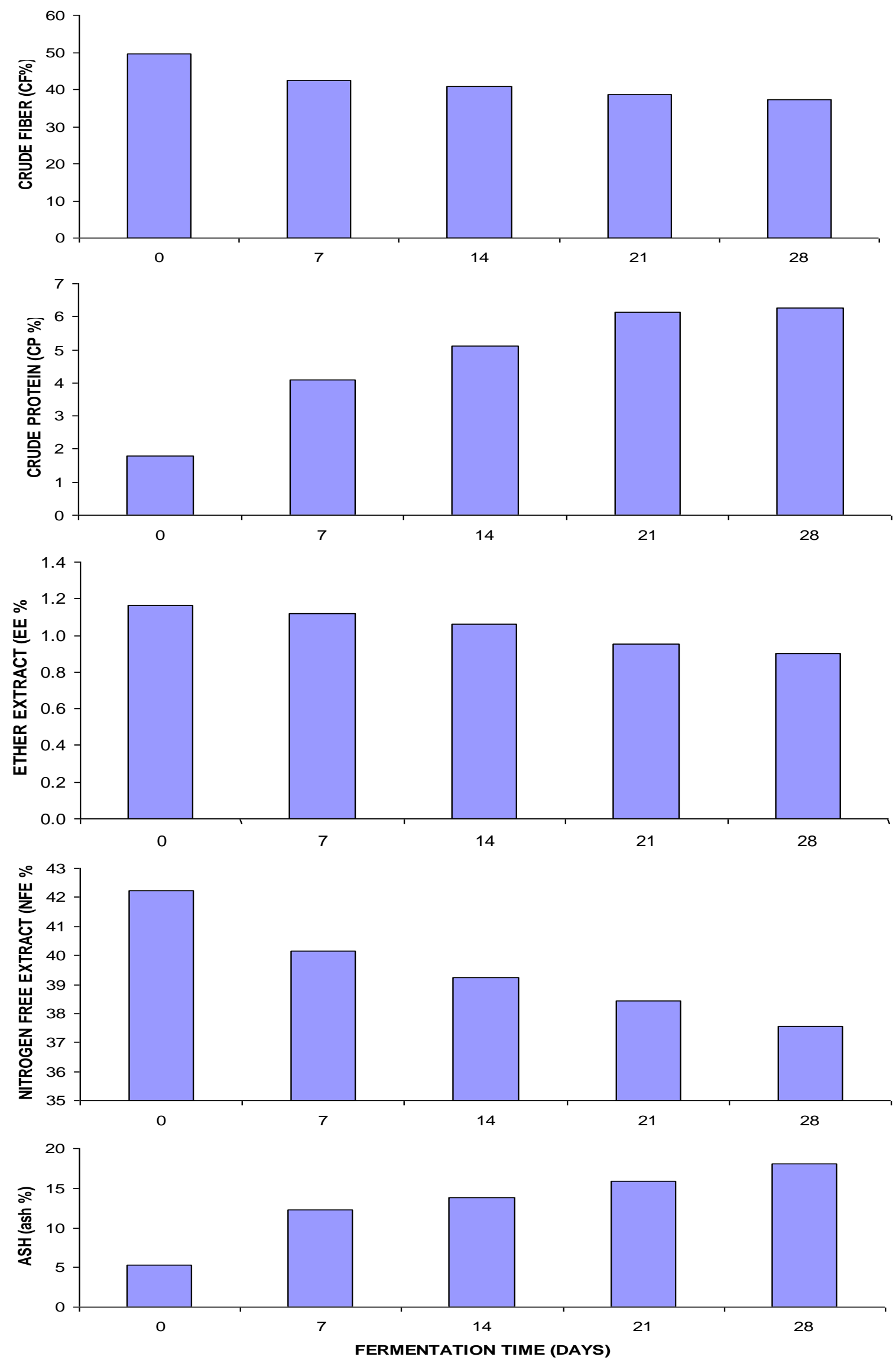

Fig (4.2), Crude protein "CP" (\%), Crude Fiber "CF" (\%), Ether Extract "EE" (\%), Nitrogen Free Extract "NFE" $(\%)$, ASH "ash" $(\%)$ at different fermentation for chemical treatment. 

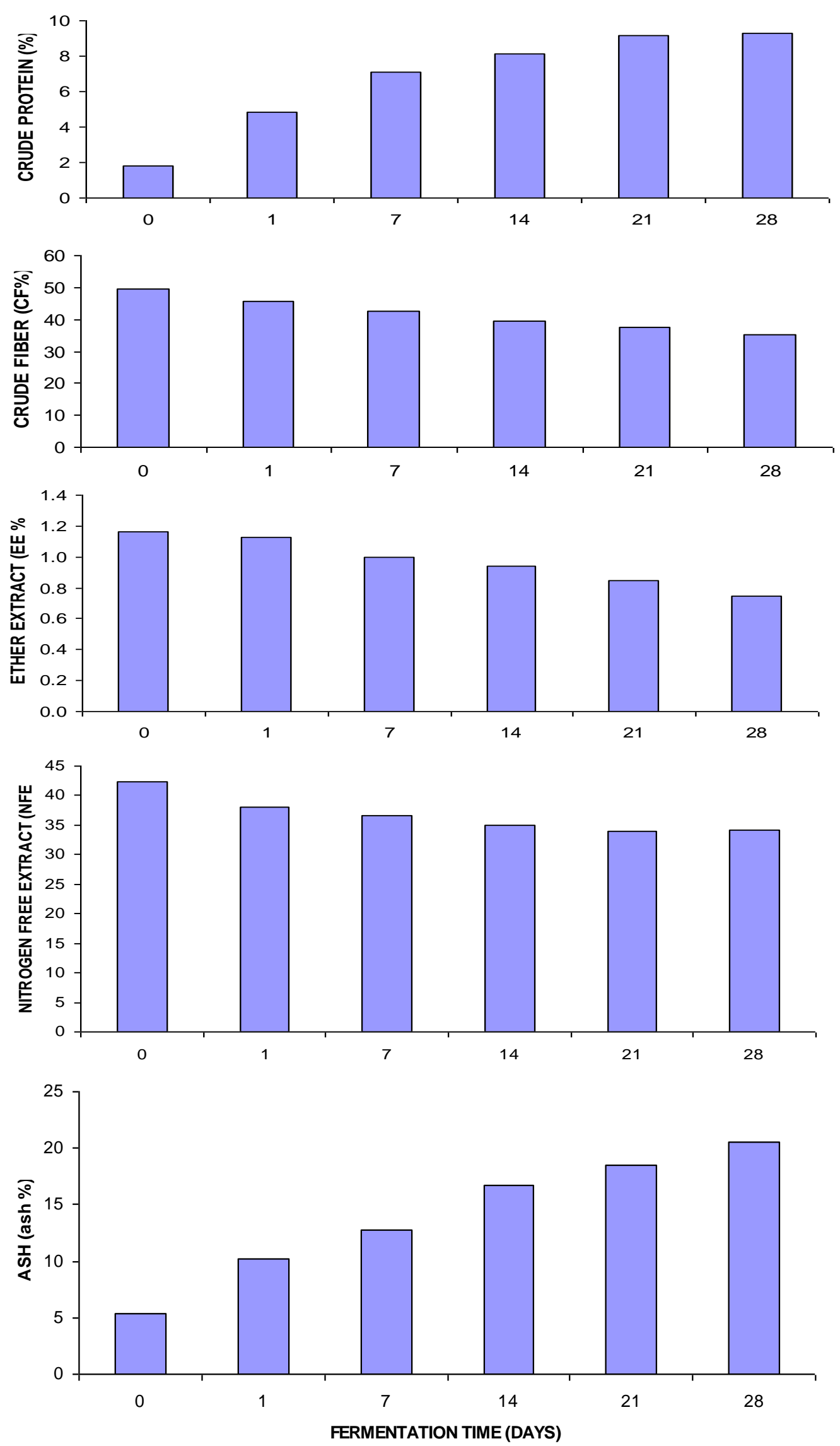

Fig (4.3), Crude protein "CP" (\%), Crude Fiber "CF" (\%), Ether Extract "EE" (\%), Nitrogen Free Extract "NFE" (\%), ASH "ash" (\%) at different fermentation for biochemical treatment. 


\section{Crude protein (CP):}

On the other hand, the increments in CP content $(9.28,6.28$ and $4.85 \%$ ) were due to biochemical, chemical and biological treatments, respectively. These results agree with those obtained by several authors (Talha, 1990; Tabana, 1994; Mohamed, 1998 and Mousa et al., 1998). These effects were mainly due to nitrogen content of added urea in the chemical treatments, microbial protein from biological treatment due to growing fungi and also to the biochemical treatments. Chandra et al. (1991) found that the increase in CP was reflected by a decrease in CF content, while, Yang et al. (2001) showed that solid state fermentation changed the composition of the bagasse. The protein content increased from $6.7 \%$ in unfermented straw to $14.7 \%$ in fermented bagasse. Generally, biochemical treatment was the best treatment which led to decrease CF content followed by a chemical treatment and a biological.

\section{Crude fiber (CF):}

The decrements in CF content $(35.15,37.25$ and $45.77 \%)$ were due to biochemical, chemical and biological treatments, respectively. The decline in crude fiber content of the experimental rations could be resultant of the enzymes secreted by the biological treatment (Gado et al., 2007). The decrease in CF content by urea treatment may be due to the liberation of cellulose from its bonds with lignin (delignification) which increased the solubility (Abd El-Ghani et al., 1999).

\section{Ether extract (EE):}

As shown in Table (4) the lowest value of ether extract (EE\%) was $0.75 \%$ recorded in biochemical treatment, followed by $(0.90$ and $1.13 \%)$. In chemical and biological treatments. These decreaement in EE due to synthesis of fatty acids through growth of fungi (Gado et al., 2007) and Rane and Singh (2001) who found that the products of solid state fermentation gets in enriched fats, soluble sugars, vitamins and amino acids and can be used entirely as in animal feed.

\section{Nitrogen free extract (NFE):}

There were decreases in the NFE contents of bagasse from $42.24 \%$ in untreated to $34.25,37.55$ and $38.02 \%$ in biochemical, chemical and biological treated bagasse respectively, whereas the lowest value (34.25\%) was recorded in biochemical. On the other side, biochemical treatment indicated lower value compared with the untreated bagasse.

\section{Ash (ASH):}

Generally, biochemical, chemical and biological treatments increased ash content, compared with the untreated bagasse. These effects were due to added media of growing fungi then degradation of DM to ash and OM. Chandra et al. (1991) found that the increased total ash on all treatments were a reflection to the decrease in CF and NFE contents. It could be concluded that all treatments had great effects on degradation of CF and increasing CP content of treated bagasse. The present finding is in agreement with Bakshi and Langer (1991), who reported that $\mathrm{CF}$ decreased from 42.92 to $17.87 \%$ in the compost and spent in a treatment with cellulose enzymes. 
Table (4.4): Effect of biological, chemical and biochemical treatments on chemical composition of sugarcane bagasse (on DM basis, \%)

\begin{tabular}{|c|l|l|l|l|l|l|l|}
\hline Item & DM & OM & CP & CF & EE & NEF & ASH \\
\hline Biological treatment & 94.15 & 90.72 & 4.85 & 45.77 & 1.13 & 38.02 & 10.22 \\
\hline Chemical treatment & 96.20 & 92.30 & 6.28 & 37.25 & 0.90 & 37.55 & 18.02 \\
\hline Biochemical treatment & 95.31 & 88.52 & 9.28 & 35.15 & 0.75 & 34.25 & 20.57 \\
\hline Untreatment & 91.90 & 94.70 & 1.80 & 49.50 & 1.16 & 42.24 & 5.30 \\
\hline
\end{tabular}

Table (4.5) the percentage of increment and decrement in CP, CF, EE, NFE, ASH, (\%) for biological, chemical and biochemical treatments.

\begin{tabular}{|c|c|c|c|c|c|}
\hline Item & $+\mathrm{CP} \%$ & $-\mathrm{CF} \%$ & $-\mathrm{EE} \%$ & $-\mathrm{NEF} \%$ & $+\mathrm{ASH} \%$ \\
\hline Biological treatment & 169.44 & 7.54 & 2.59 & 9.99 & 92.83 \\
\hline Chemical treatment & 248.89 & 24.75 & 22.41 & 11.10 & 240 \\
\hline Biochemical treatment & 415.56 & 28.99 & 35.34 & 18.92 & 288.11 \\
\hline
\end{tabular}

\section{CONCULATIONS}

The experimental work was conducted during December 2017 at Tractors and Farm machinery Testing \& Research Station at Sabahia, Alexandria Governorate, Egypt, The present study aimed to study the possibility of improving utilization of sugarcane bagasse as feeds for ruminants using chemical (4\% urea), biological "Trichoderma harzinaum F-418 fungi", and biochemical treatment (combined biological + urea). The experiment included three treatments each treatment was replicated three times in RCB design.

As well as control treatment Data were recorded for crude protein content "CP" (\%), crude fiber content "CF" (\%), Ether extract content "EE" (\%), ASH content "Ash" (\%) and Nitrogen free extract content "NFE" (\%) to maximize its nutritional values in order to use such improved materials as animal feeds. The results showed that different treatments increased DM, CP, and ash, while decreased OM, CF, EE and NFE. The increments in CP content were 288.11, 240.00 and $92.83 \%$ due to biochemical, chemical and biological treatments, respectively. While the decrement in CF content were 28.99, 24.75 and 7.54\% due to biochemical, chemical and biological treatments, respectively. Values of dry matter and organic matter disappearance were significantly higher $(\mathrm{P}<0.05)$ for biochemical, chemical and biological treated bagasse, respectively, than untreated bagasse.

\section{REFERENCES}

Abd-Alla S. A. E. (2007), Biological treatment of some by-products in ruminants feeding. M. Sc. Fac of Agric. Al-Azhar Univ. Cairo.

Abd El-Azim S. N., M. A. Ahmed, F. Abo-Donia and H. Soliman (2011), Evaluation of fungal treatment of some agricultural residues, Egyptian Journal of Sheep \& Goat Sciences, $6(2): 1-13$.

Agriculture Economic and Statistics Institute, Ministry of Agriculture and Land Reclamation (1995). Agric. Economics. Part 1, Arguers. Cent. Ministry of Agriculture and Land Reclamation.

Abd El-Ghani, A. A.; F. M. R. El-Feel; E. Shehata and E. Ibrahim (1999). Influence of feeding banana plant wastes treated by urea or sodium hydroxide on digestibility, rumen 
fermentation characteristics and performance of growing sheep. J. Agric. Sci., Mansoura Univ., 24:107.

Ahuja, A. K.; V. K. Kakkar; H. S. Garcha and G. S. Mokkar (1986). Spent paddy straw as a basal roughage for sheep. Ind. J. of Anim. Sci. 56(2): 285.

Bakchevanska S. (1988), A feed by-product from straw. Zhivo Inov dni Nauki. 24:49 Vissh Inst. Khranitelnovkusova promishlenost Plovdiv, Bulgaria. (Nut. Abst. Rev., 8:579).

Bakshi, M. P. S. and P. N. Langer (1991). Agaricus bisporus harvested spent wheat straw as live stock feed. Indian J. Anim. Sci. 61(6): 653.

Bassuny, S. M.; Abd El-Aziz, A. A.; EL-Sayis, M. F. and Abdulla,M. A. (2003) Fibrous crop by-products as feed. 2. Effect of chemical and biochemical treatments on feed intake, nutritive values and some ruminal and blood constituents. Egyptian J. Nutrition and Feeds, 6 (Special Issue): 901-912.

Boraei, M. A. (2003) Utilization of different fiber sources in ruminants nutrition. Egyptian J. Nutrition and Feeds 6 (Special Issue) : 1267-1277.

Chandra, S.; M. R. Reddy and G. V. N. Reddy (1991). Effect of fungal treatment of paddy straw on nutrient utilization in complete diets for sheep. Indian j. of Anim. Sci.61 (12): 1330.

Conrad, J. H.; M. I. Floriqto and L. R. McDowell (1990). Produccion de $2000 \mathrm{Kg}$ de carne vacuna utilizando una ha de cana de azucar. Conferencia Internacional Sobre la Ganaderia en los Tropicos. Centro de Agricultura Tropical, Universidad de Florida, USA.

Dawson, K. A.; K. E. Newman and J. A. Boling (1990). Effects of microbial supplements containing yeast and lactobacilli on roughage fed animal microbial activities. J. Anim. Sci. 68: 3392.

El-Ashry, M.A.; H.M. El-Sayed; M. Fadel; H.M. Metwally and M.M. Khorshed (2002). Effect of chemical and biological treatments of some crop residues on their nutritive value: 2- Effect of biological treatment on chemical composition and in vitro disappearance. Egypt. J. Nutr. and Feeds. 5 (1): 43.

El-Shinnawy M. M. (1990), The role of fibrous residues in feeding ruminants. 3rd Intern. Symp. On feed Manufac. And quality control.: 321-326.

El-Shinnawy, M. M. and Shoukry, M. M. (2002). Country report for Egypt on the study of the possibility of the production and manufacturing of feeds integration in the Arab country organization for agricultural development.

Fadel, M. (1989) Production of fodder yeast using cellulatic wastes. Ph. D. Thesis. Fac. of Agric. Cairo Univ. pp:37.

Fouad, R. T.; T. A. Deraz and S. A. Atiat Ismail (1998). Biological versus urea treatment of roughages for sheep. J. Agric. Sci., Mansoura Univ., 23:103.

Gado, H. M.; H. M. Metwally; H. S. Soliman and Etab R. I. Abd El-Galil (2007). Effect of biological treatments by cellulolytic bacteria on chemical composition and cell wall constituents of some roughages. Egyptian J. Nutr. and Feeds. 10(1): 123.

Hamdia M. Moussa; Rania M. Barghash and Ahlam A. Hassan (2011), The Current Situation of the Animal Feed Gap in Egypt J. Basic. Appl. Sci. Res., 1(7)713-720.

Khairy, M. F. A., Mohamed, A. I., Nabih, M. M. M (2015), Development of bioreactor to enrich the protein of agricultural residues, Misr J. Ag.Eng., 32(4): 1625-1640. 
Kholif S. M. (2001), Effect of biological treatment of low quality roughage on milk yield and composition. Ph. D. Thesis. Fac. Agric. Ain Shams Univ.

Langar P. N., J. P. Sehgal and H. S. Garcha (1980), Chemical changes in wheat and paddy straw after fungal cultivation. Indian J. Anim. Sci., 50 (11): 942-946.

Mohamed, F. G. A. (1998) Improving the nutritive value of roughage used for rabbit feeding. Ph.D. Thesis, Fac. Agric. Ain-Shams University, Cairo.

Molina, A. (1990). Potencial forrajero de la cana de azucar para la ceba de ganado bovino.Edica Cuba.

Mousa, M.; A. A. Abd El-Ghani and A. H. Sadiek (1998). Influence of feeding different levels of improved corn stover on sheep performance and health. J. Agric. Mansoura Univ., 23(6): 2416.

Nabih, M. M. M., (2015), Magnifying Agricultural Residues Benefits, Ph.D Thesis. Faculty of Agricultural Al-Azhar University.

Preston, R. L. (2003) Feed composition guide, Texas Techn. Univ., 191 Columbia Court, Pagosa Springs, CO., U.S.A.

Rane, S. and K. Singh (2001). Improvement in nutritive value of poor quality roughages through SSFENLAC process using hydrolytic enzymes and Nfixing bacteria. Indian Dairy Man, 53:59.

Shahjahan B., I. Z. Saeed and F. H. Shah (1986), Rice husk biodegradation by Pleurotus to produce ruminants feed. Agric. Wastes, (17)15-21.

Shakweer, I. M. E. ( 2003 ) Effect of biological treatments of rice straw and sugarcane bagasse on their digestibility, nutritive value, ruminal activity and some blood parameters in rams . Egyptian J. Nutrition and Feeds (2003), 6 (Special Issue): 925-940.

Shoukry, M. M. (1992). Effect of urea treatment on chemical composition, in vitro dry matter disappearance and digestibility of dry matter and cell wall constituents of some poor quality roughages. Annals of Agric. Sci. Moshtohor, 30 (2):677.

Shoukry M. M., F. A. Hamissa, M. Sawsan, A. H. El-Refi, H. M. Ali and Z. M. AbdelMotagally (1985), Nutritive improvement of some low quality roughages for ruminants. 1- Effect of different micerobial and chemical treatments on quality of sugarcane bagasse. Egypt. J. Anim. Prod., 25-329.

Smail T., O. Salhi and J. S. Knapp (1995), Solid state fermentation of carob pods by Aspergillus niger for protein production: effect of particle size. World J. Microb. Biotech. 11:171.

Snedecor G.W. and W.G. Cochran (1971), Statistical Methods. 6 th Ed.,Iowa State Univ. Press, Ames, Iowa, USA.

Tabana, A. S. A. (1994). Utilization of corn and sunflower plant residues for ruminant nutrition. M. Sc. Thesis, Fac. of Agric., Ain- Shams Univ.

Talha, M. H. A. (1990). Effect of urea treatment on the utilization of corn stalks by ruminants. M. Sc. Thesis, Fac. of Agric., Ain- Shams Univ.

Yang, X.; H. Chen; H. Gao and Z. Li (2001). Bioconversion of corn straw by coupling ensiling and solid state fermentation. Biores. Techn. 78. 277. 


\section{تأثير المعالجات البيولوجية والكيميائية والبيوكيميائية على الخواص الكيميائية لمصاصة قصب السكر في المفاعل والبوكيمبالية المطور

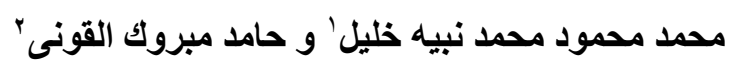

' معهد بحوث الهندسة الزراعية - مركز البحوث الزر اعية ـ الدقي - جيزة - مصر.

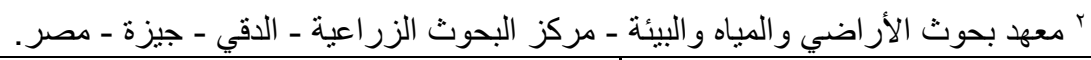

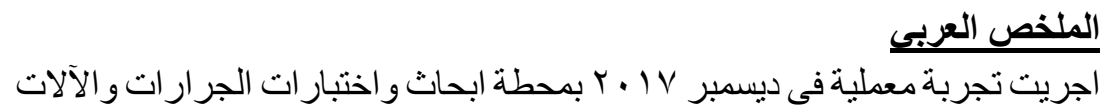

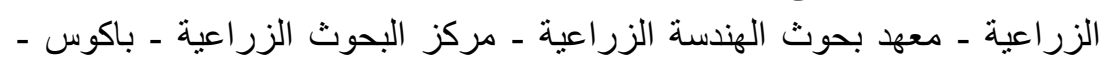

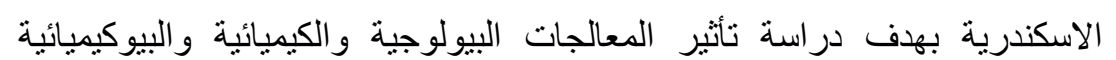

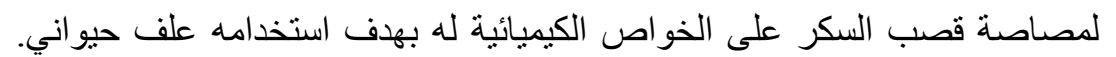

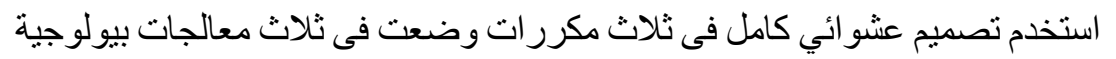

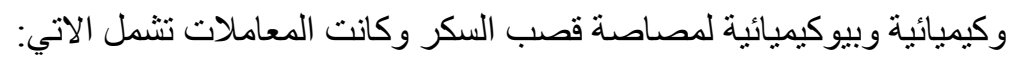

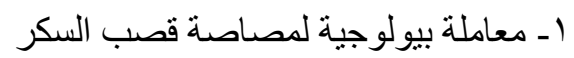

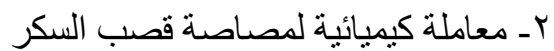

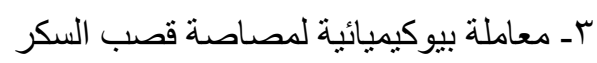

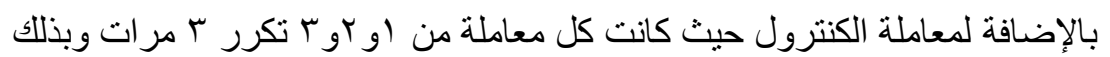

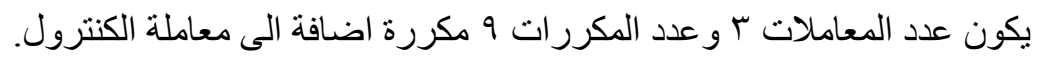

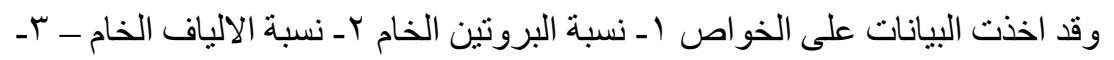

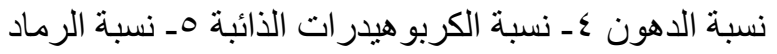

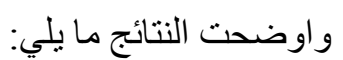

1 ـ ازدياد نسبة البروتين الخام ونسبة الرماد فى مختلف المعالجات بينما نقصت كل

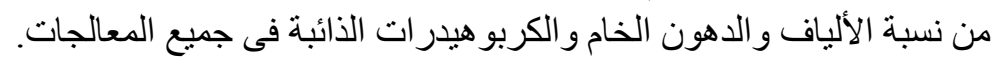

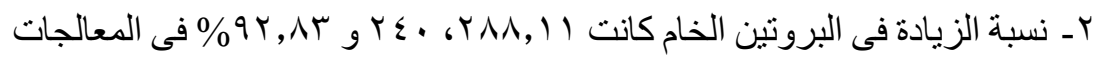

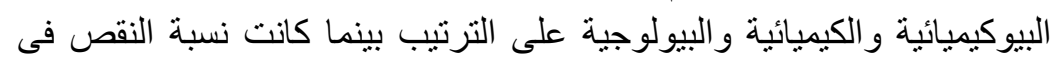

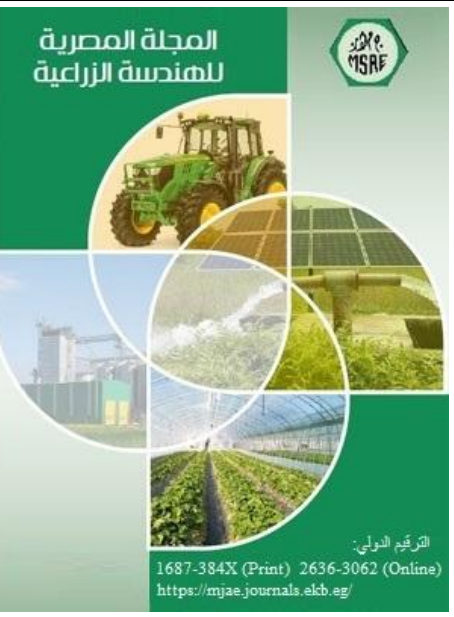

(م) المجلة المصرية للهندسة الزراعية

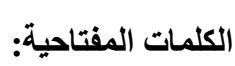
المفاعل المطور، مصاصة قصبة:

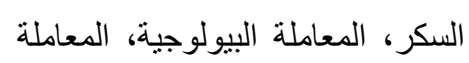

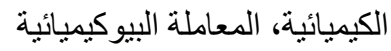

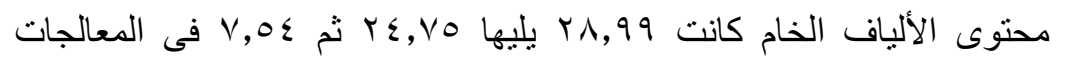
البيوكيميائية و الكيميائية و البيولوجية على الترتيب. 